\title{
Microbial production of Propionic and Succinic acid from Sorbitol using Propionibacterium acidipropionici
}

\author{
Juliana C Duarte ${ }^{1,2}$, Gustavo P Valença ${ }^{2}$, Paulo J S Moran ${ }^{1}$ and J Augusto R Rodrigues ${ }^{1 *}$
}

\begin{abstract}
Three sequential fermentative batches were carried out with cell recycle in four simultaneously operating bioreactors maintained at $\mathrm{pH} 6.5,30^{\circ} \mathrm{C}$, and $100 \mathrm{rpm}$. P. acidipropionici ATCC 4875 was able to produce propionic and succinic acid from sorbitol. The concentration of propionic acid decreased slightly from $39.5 \pm 5.2 \mathrm{~g} \mathrm{~L}^{-1}$ to $34.4 \pm 1.9 \mathrm{~g} \mathrm{~L}^{-1}$, and that of succinic acid increased significantly from $6.1 \pm 2.1 \mathrm{~g} \mathrm{~L}^{-1}$ to $14.8 \pm 0.9 \mathrm{~g} \mathrm{~L}^{-1}$ through the sequential batches. In addition, a small amount of acetic acid was produced that decreased from $3.3 \pm 0.4 \mathrm{~g} \mathrm{~L}^{-1}$ to $2.0 \pm 0.3 \mathrm{~g} \mathrm{~L}^{-1}$ through the batches. The major yield for propionic acid was $0.613 \mathrm{~g} \mathrm{~g}^{-1}$ in the first batch and succinic acid it was $0.212 \mathrm{~g} \mathrm{~g}^{-1}$ in the third batch. The minor yield of acetic acid was $0.029 \mathrm{~g} \mathrm{~g}^{-1}$, in the second and third batches.
\end{abstract}

Keywords: Propionibacterium acidipropionici; Sorbitol; Propionic acid; Succinic acid; Batch fermentation

\section{Introduction}

Propionibacterium acidipropionici has been widely studied for the heterofermentative production of propionic acid, including fermentation on a semi-industrial scale (Zhu et al. 2010). Propionic acid and its salts are valuable industrial products with several applications such as mold-inhibitors, preservatives for animal and human food, fruit flavorings, additives in cellulosic plastics, and herbicides and medications for animal therapy (Boyaval and Corre 1995). Consumption by the animal world was estimated at 293.4 thousand tons in 2009, representing a market of approximately $\$ 530$ million with an expected rate of 3.9\% until 2014 (Bizzari and Gubler 2004). Currently, industrial production of propionic acid utilizes fossil-based resources. However, the finite nature of oil and the rise in its price increased customer awareness and demand for green products. Furthermore, increased costs waste disposal and restrictions on land filling for certain types of waste led to increased interest in a more sustainable production of chemicals and materials from renewable bio-based raw materials (Tsoskounogiou et al.

\footnotetext{
* Correspondence: jaugusto@iqm.unicamp.br

'Institute of Chemistry, University of Campinas, Campinas, SP 13083-970, Brazil

Full list of author information is available at the end of the article
}

2008). The conversion of bio-based residues or byproducts into valuable chemicals offers several potential advantages: low product cost, less environmental impact, less energy requirement, and less toxic products.

The production of propionic acid by fermentation using Propionibacterium sp has been investigated during the last decade. These microorganisms are able to grow and produce propionic acid using several cheap industrial and agricultural by-products and residues that serve as Csource. These cheap sources are biodiesel glycerol (Ruhal et al. 2011), molasses (Feng et al. 2011), fish hydrolysate (Mahmoud and Levin 1993), lactose whey (Yang et al. 1995), hydrolyzed corn meal (Huang et al. 2002), glucose (Koussémon et al. 2003), wheat flour (Kagliwal et al. 2013; Sabra et al. 2013), and several other by-products including mixtures of glycerol and glucose (Wang and Yang 2013).

Succinic acid has a wide range of industrial application, for example as a chemical intermediate for the production of lacquers and perfume esters as well as flavoring, bacteriostatic, or neutralizing agent in the food industry. Furthermore, succinic acid also has a special chemical market for the production of coatings, surfactants dyes, detergents, green solvents, biodegradable plastics, and the stimulation of animal and plant growth. With its linear and saturated dicarboxylic acid structure, 
succinic acid can be readily converted to other chemicals, such as 1,4-butanediol (Minh et al. 2010), gammabutyrolactone, tetrahydrofuran, adipic acid, $N$-methylpyrrolidone, or linear aliphatic esters. With various environmental implications, the demand for succinic acid is expected to increase significantly. A new biodegradable polymer, poly (1,3-propylene succinate), can be derived by the polycondensation of succinic acid with 1,3-propanediol and also with thermoplastic poly(butylene succinate) (Ranucci et al. 2000). While the current global succinic acid production is approximately 30,000 to 50,000 tons per year with a market price of US\$2400-3000 per ton, the market is expected to reach 100,000 tons per year by 2015 (Adsul et al. 2011).

Succinic acid can be produced via chemical routes by paraffin oxidation, catalytic hydrogenation, or electroreduction of maleic acid or maleic anhydride (Muzumdar et al. 2004). Recent developments have focused on biotechnological alternatives, in particular microbial transformation based on the use of renewable biomass as feedstock (Cheng et al. 2012; Hatti-Kaul et al. 2007).

Notably, even after 100 years of accumulated research on propionibacteria, propionic acid is still produced via petrochemical routes, and no industrial biotechnological process has been established for these organisms. The main hindrances have been low productivity, low final product concentration, slow growth, high end-product inhibition, and costly downstream separation from subproducts (Blanc and Goma 1987; Goswami and Srivastava 2001). Our interest in the present article is to explore new sources of materials and particularly sorbitol. This inexpensive polyol has been subjected to fermentation by P. acidipropionici in a $\mathrm{PhD}$ thesis (Suwannakham 2005), but until now no article has been published. Sorbitol has a high reduction degree (4.33) (VanBriesen 2002) that favors the production of more reduced metabolites. We expect to minimize the amount of acetic acid produced and to maximize the formation of propionic and succinic acid in a fermentation process using $P$. acidipropionici ATCC 4875 .

\section{Materials and Methods Chemicals}

Sorbitol was purchased from Sigma-Aldrich Co., USA, and yeast extract from Oxoid Ltd., England. $\mathrm{CaCl}_{2} \cdot 2 \mathrm{H}_{2} \mathrm{O}$, $\mathrm{CoCl}_{2} \cdot 6 \mathrm{H}_{2} \mathrm{O}, \mathrm{MnSO}_{4} \cdot \mathrm{H}_{2} \mathrm{O}, \mathrm{ZnSO}_{4} \cdot 7 \mathrm{H}_{2} \mathrm{O}, \mathrm{KH}_{2} \mathrm{PO}_{4}$, and $\left(\mathrm{NH}_{4}\right)_{2} \mathrm{HPO}_{4}$ were purchased from Synth Ltda., Brazil. $\mathrm{MgSO}_{4} \cdot 7 \mathrm{H}_{2} \mathrm{O}$ was purchased from Nuclear, Brazil and $\mathrm{FeSO}_{4} .7 \mathrm{H}_{2} \mathrm{O}$ was purchased from Vetec Ltda, Brazil.

\section{Bioreactors}

A 3.6 L Infors-HT-Labors bioreactor was used for biomass growth, and two 0.5 L Infors-HT-Multifors, each one equipped with two parallel vessels, were used to promote batch fermentations. All bioreactors are equipped with $\mathrm{pH}$ and temperature sensors, agitation, and $\mathrm{N}_{2}$ flow control.

\section{Microorganism's growth and fermentation medium}

The Propionibacterium acidipropionici ATCC 4875 used in this study was grown in a synthetic medium using $10 \mathrm{~g} \mathrm{~L}^{-1}$ sorbitol as a carbon source, $10 \mathrm{~g} \mathrm{~L}^{-1}$ yeast extract, $1 \mathrm{~g} \mathrm{~L}^{-1} \mathrm{KH}_{2} \mathrm{PO}_{4}, 2 \mathrm{~g} \mathrm{~L}^{-1}\left(\mathrm{NH}_{4}\right)_{2} \mathrm{HPO}_{4}$, and the following micronutrients: $5 \mathrm{mg} \mathrm{L}^{-1} \mathrm{FeSO}_{4} \cdot 7 \mathrm{H}_{2} \mathrm{O}, 10 \mathrm{mg} \mathrm{L}^{-1}$ $\mathrm{MgSO}_{4} .7 \mathrm{H}_{2} \mathrm{O}, 2.5 \mathrm{mg} \mathrm{L}^{-1} \mathrm{MnSO}_{4} \cdot \mathrm{H}_{2} \mathrm{O}, 5 \mathrm{mg} \mathrm{L}^{-1}$ $\mathrm{ZnSO}_{4} .7 \mathrm{H}_{2} \mathrm{O}, 10 \mathrm{mg} \mathrm{L} \mathrm{CaCl}_{2} \cdot 2 \mathrm{H}_{2} \mathrm{O}, 10 \mathrm{mg} \mathrm{L}$ $\mathrm{CoCl}_{2} \cdot 6 \mathrm{H}_{2} \mathrm{O}$ (Coral et al. 2008). In the fermentation medium, only the sorbitol concentration was changed from 10 to $80 \mathrm{~g} \mathrm{~L}^{-1}$. The dry cell weight (DCW) was calculated from the $\mathrm{OD}_{600}$ value. One unit of $\mathrm{OD}_{600}$ was equivalent to $0.431 \mathrm{~g} \mathrm{~L}^{-1} \mathrm{DCW}$. The meaning of these abbreviations can be found in Table 1 .

\section{Pre-inoculum and inoculum preparation}

The pre-inoculum was prepared using $1.5 \mathrm{~mL}$ of an ultra-low temperature preserved culture that was thawed on ice and transferred to a $15 \mathrm{~mL}$ screw-cap flask containing $13.5 \mathrm{~mL}$ of the growth medium described above and then incubated at $30^{\circ} \mathrm{C}$ for $24 \mathrm{~h}$ without agitation.

\section{Table 1 List of nomenclature}

\begin{tabular}{|c|c|}
\hline Abbreviations & Meaning \\
\hline $\mathrm{Y}_{\mathrm{X} / \mathrm{S}}$ & Yield of biomass with respect to substrate $\left(\mathrm{g} \mathrm{g}^{-1}\right)$ \\
\hline $\mathrm{Y}_{\mathrm{SA} / \mathrm{S}}$ & Yield of succinic acid with respect to substrate $\left(\mathrm{g} \mathrm{g}^{-1}\right)$ \\
\hline $\mathrm{Y}_{\mathrm{AA} / \mathrm{S}}$ & Yield of acetic acid with respect to substrate $\left(\mathrm{g} \mathrm{g}^{-1}\right)$ \\
\hline $\mathrm{Y}_{\mathrm{PA} / \mathrm{S}}$ & Yield of propionic acid with respect to substrate $\left(\mathrm{g} \mathrm{g}^{-1}\right)$ \\
\hline $\mathrm{Y}_{\mathrm{SA} / \mathrm{X}}$ & Yield of succinic acid with respect to biomass $\left(\mathrm{g} \mathrm{g}^{-1}\right)$ \\
\hline $\mathrm{Y}_{\mathrm{AA} / \mathrm{X}}$ & Yield of acetic acid with respect to biomass $\left(\mathrm{g} \mathrm{g}^{-1}\right)$ \\
\hline $\mathrm{Y}_{\mathrm{PA} / \mathrm{X}}$ & Yield of propionic acid with respect to biomass $\left(\mathrm{g} \mathrm{g}^{-1}\right)$ \\
\hline m & Cell maintenance $\left(\mathrm{g} \mathrm{g}^{-1} \mathrm{~h}^{-1}\right)$ \\
\hline$r_{s}$ & Instantaneous substrate consumption rate $\left(\mathrm{g} \mathrm{h}^{-1}\right)$ \\
\hline$r_{\mathrm{SA}}$ & Instantaneous succinic acid production rate $\left(\mathrm{g} \mathrm{h}^{-1}\right)$ \\
\hline $\mathrm{r}_{\mathrm{AA}}$ & Instantaneous acetic acid production rate $\left(\mathrm{g} \mathrm{h}^{-1}\right)$ \\
\hline$r_{P A}$ & Instantaneous propionic acid production rate $\left(\mathrm{g} \mathrm{h}^{-1}\right)$ \\
\hline$r_{x}$ & Instantaneous cell growth rate $\left(\mathrm{g} \mathrm{h}^{-1}\right)$ \\
\hline$\mu_{\mathrm{s}}$ & Specific substrate consumption rate $\left(h^{-1}\right)$ \\
\hline$\mu_{\mathrm{SA}}$ & Specific succinic acid production rate $\left(\mathrm{h}^{-1}\right)$ \\
\hline$\mu_{\mathrm{AA}}$ & Specific acetic acid production rate $\left(h^{-1}\right)$ \\
\hline$\mu_{\mathrm{PA}}$ & Specific propionic acid production rate $\left(\mathrm{h}^{-1}\right)$ \\
\hline$\mu_{\mathrm{x}}$ & Specific cell growth rate $\left(\mathrm{h}^{-1}\right)$ \\
\hline DCW & Dry cell weight \\
\hline$O D_{600}$ & Optical density at $600 \mathrm{~nm}$ \\
\hline $\mathrm{P} / \mathrm{A}$ & Ratio of propionic to acetic acid ( $\mathrm{mol} \mathrm{mol}{ }^{-1}$ or $\mathrm{g} \mathrm{g}^{-1}$ ) \\
\hline S/A & Ratio of succinic to acetic acid ( $\mathrm{mol} \mathrm{mol}^{-1}$ or $\mathrm{g} \mathrm{g}^{-1}$ ) \\
\hline FBB & Fibrous bed bioreactor \\
\hline
\end{tabular}


After $24 \mathrm{~h}$ the inoculum was prepared by transferring $5 \mathrm{~mL}$ of the pre-inoculum to a $50 \mathrm{~mL}$ screw-cap flask containing $45 \mathrm{~mL}$ of the growth medium described above (in duplicate). P. acidipropionici was incubated at $30^{\circ} \mathrm{C}$ for $48-50 \mathrm{~h}$ without agitation (final $\mathrm{OD}_{600} \sim 2.5$ ), and the total inoculum amount $(100 \mathrm{~mL})$ was inoculated into $900 \mathrm{~mL}$ of the fermentation medium in a Infors-HT Labfors bioreactor to promote biomass growth.

\section{Biomass growth}

To promote biomass growth, $P$. acidipropionici was grown in $1 \mathrm{~L}$ of the fermentation medium described above (sorbitol $80 \mathrm{~g} \mathrm{~L}^{-1}$ ). Growth was carried out in the Infors-HT Labfors bioreactor for $48 \mathrm{~h}$ at $30^{\circ} \mathrm{C}, \mathrm{pH} 6.5$ $\left(\mathrm{NaOH} 4 \mathrm{~mol} \mathrm{~L}^{-1}\right)$, and $100 \mathrm{rpm}$ under anaerobic conditions ( $\mathrm{N}_{2}$ bubbling) for the first 30 minutes. The medium was then divided in four $500 \mathrm{~mL}$ screw-cap flasks, each one containing $250 \mathrm{~mL}$ of medium, and centrifuged at $3000 \mathrm{rpm}$ for 20 minutes. All the supernatants were discarded and the cells were suspended in $250 \mathrm{~mL}$ of fresh fermentation medium.

\section{Sequential batch fermentation}

Sequential batch fermentations were performed in two independent Infors-HT Multifors bioreactors, each one equipped with two parallel vessels operating simultaneously and containing $250 \mathrm{~mL}$ of fresh fermentation medium as described above. Each sequential batch fermentation was carried out for $70 \mathrm{~h}$ at $30^{\circ} \mathrm{C}, \mathrm{pH} 6.5$ $\left(\mathrm{NaOH} 4 \mathrm{~mol} \mathrm{~L}^{-1}\right)$, and $100 \mathrm{rpm}$ under anaerobic conditions $\left(\mathrm{N}_{2}\right.$ bubbling) for the first 15 minutes. Samples of $1.5 \mathrm{~mL}$ were aseptically removed at the beginning of the fermentation and at periodic intervals of $24 \mathrm{~h}$. After $70 \mathrm{~h}$, each medium was transferred to a $500 \mathrm{~mL}$ screwcap flask and centrifuged at $3000 \mathrm{rpm}$ for 20 minutes. The supernatants were discarded and the cells were suspended in a fresh medium. The flasks containing the cells in fresh medium were transferred aseptically to the bioreactor to start new batch fermentation. Each batch was simultaneously made in quadruplicate.

\section{Quantitative analysis \\ Carbon source and organic acids determination}

Sorbitol, succinic, acetic, and propionic acid concentrations were determined by high-performance liquid chromatography (Agilent 1200 series) using an Aminex ${ }^{\odot} \mathrm{HPX}-87 \mathrm{H}$ ion exclusion column (Bio-Rad, Hercules, CA, USA) operated at $50^{\circ} \mathrm{C}$, with $5 \mathrm{mmol} \mathrm{L}^{-1} \mathrm{H}_{2} \mathrm{SO}_{4}$ as the mobile phase

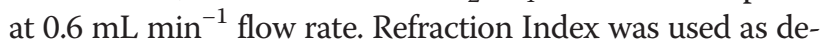
tector. Samples for analysis were centrifuged at $5000 \mathrm{rpm}$ for 15 minutes, filtered through $0.22-\mu \mathrm{m}$ pore-size filters (Millipore), and diluted with purified water (milliQ). The product and substrate concentrations were calculated using the peak areas in calibration curves equations.

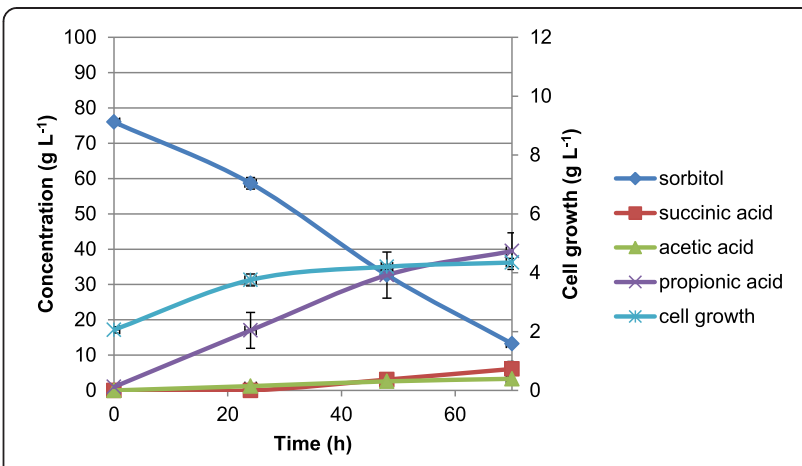

Figure 1 Profile of sorbitol fermentation by $P$. acidipropionici for the first batch operating in four independent vessels simultaneously.

\section{Results}

Three sequential batches in two independent bioreactors, each one with two parallel vessels (four reactors) operating simultaneously, were carried out with $P$. acidipropionici ATCC 4875 using sorbitol as a carbon source. The results for the first batch are presented in Figure 1. It was observed that sorbitol was not completely consumed after $70 \mathrm{~h}$, and its final concentration was $13.3 \pm$ $0.9 \mathrm{~g} \mathrm{~L}^{-1}$. The final concentrations of succinic, acetic, and propionic acid were $6.1 \pm 2.1,3.3 \pm 0.4$, and $39.5 \pm$ $5.2 \mathrm{~g} \mathrm{~L}^{-1}$, respectively. Cell growth was also observed, and the final cellular concentration was $4.3 \pm 0.1 \mathrm{~g} \mathrm{~L}^{-1}$. In the second sequential batch, contrarily to the first batch, the substrate consumption was almost complete after $70 \mathrm{~h}$, and its final concentration was $1.2 \pm 1.3 \mathrm{~g} \mathrm{~L}^{-1}$. The final concentrations of succinic, acetic, and propionic acid were $10.0 \pm 1.3,2.2 \pm 0.1$, and $35.8 \pm 1.4 \mathrm{~g} \mathrm{~L}^{-1}$, respectively. The final concentration of succinic acid increased while that of acetic and propionic acid decreased, compared with the first batch. As expected, cell growth was observed, and the final cellular concentration increased up to $6.1 \pm 0.3 \mathrm{~g} \mathrm{~L}^{-1}$ (Figure 2). In the last sequential batch, substrate consumption was completed before $70 \mathrm{~h}$, and the final concentrations of succinic,

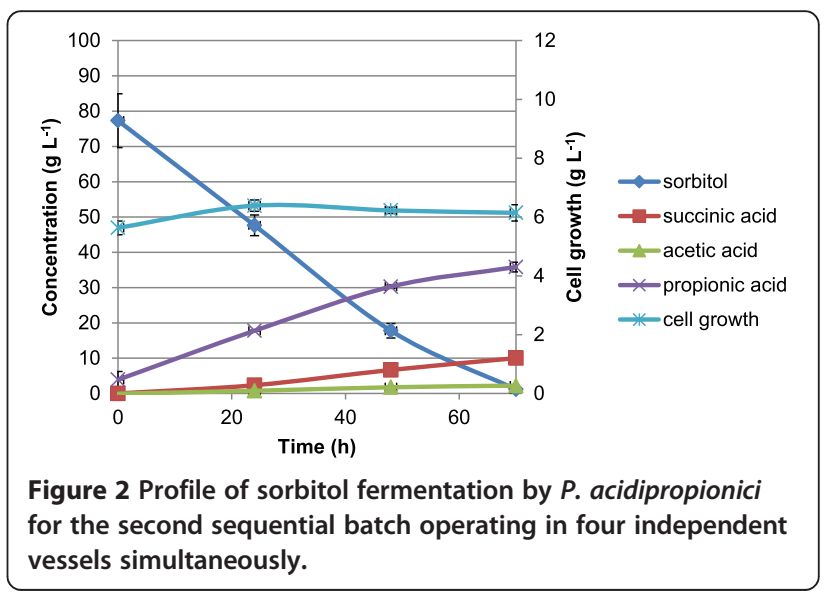




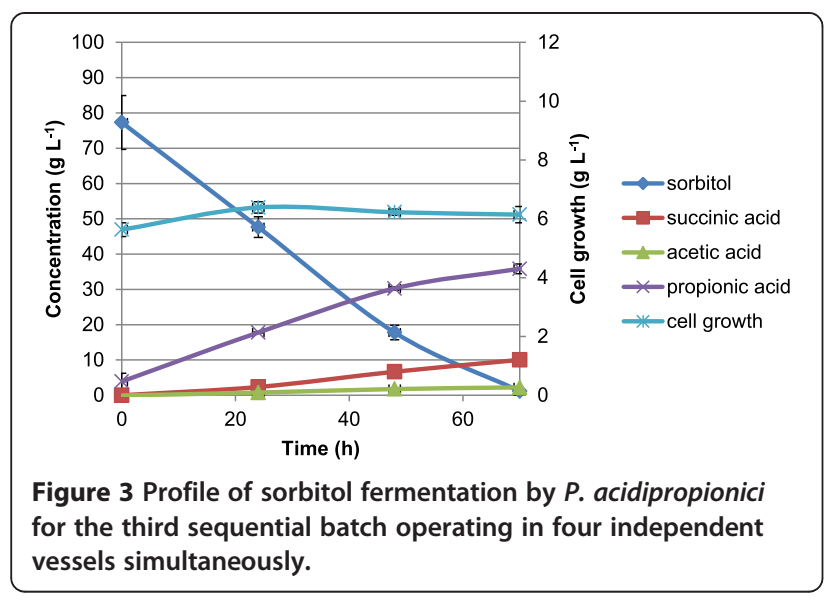

acetic, and propionic acid were 14.8 $\pm 0.9,2.0 \pm 0.3$, and $34.4 \pm 1.9 \mathrm{~g} \mathrm{~L}^{-1}$, respectively. Cell growth was still observed, and the final cellular concentration increased to $9.9 \pm 0.5 \mathrm{~g} \mathrm{~L}^{-1}$ (Figure 3). Accordingly, the final concentration of succinic acid increased (from $6.1 \pm 2.1 \mathrm{~g} \mathrm{~L}^{-1}$ in the first batch to $14.8 \pm 0.9 \mathrm{~g} \mathrm{~L}^{-1}$ in the third sequential batch), that of acetic acid decreased (from $3.3 \pm$ $0.4 \mathrm{~g} \mathrm{~L}^{-1}$ in the first batch to $2.0 \pm 0.3 \mathrm{~g} \mathrm{~L}^{-1}$ in the third sequential batch) as well as that of propionic acid (from $39.5 \pm 5.2 \mathrm{~g} \mathrm{~L}^{-1}$ in the first batch to $34.4 \pm 1.9 \mathrm{~g} \mathrm{~L}^{-1}$ in the third sequential batch) in the sequential batches. A profile change was noticed in sorbitol consumption and product formation throughout the sequential batches, as shown in Figure 4. Furthermore, the overall final results and the carbon recovery for each sequential batch are summarized in Table 2.
Table 2 Substrate, organic acids, cellular final concentrations, and recovered carbon for the three sequential fermentation batches using $P$. acidipropionici operating in four independent vessels

\begin{tabular}{lrcr}
\hline & First batch & Second batch & Third batch \\
\hline Sorbitol $\left(\mathrm{g} \mathrm{L}^{-1}\right)$ & $13.3 \pm 0.9$ & $1.2 \pm 1.3$ & $0.0 \pm 0.0$ \\
Succinic acid $\left(\mathrm{g} \mathrm{L}^{-1}\right)$ & $6.1 \pm 2.1$ & $10.0 \pm 1.3$ & $14.8 \pm 0.9$ \\
Acetic acid $\left(\mathrm{g} \mathrm{L}^{-1}\right)$ & $3.3 \pm 0.4$ & $2.2 \pm 0.1$ & $2.0 \pm 0.3$ \\
Propionic acid $\left(\mathrm{g} \mathrm{L}^{-1}\right)$ & $39.5 \pm 5.2$ & $35.8 \pm 1.4$ & $34.4 \pm 1.9$ \\
Cell $\left(\mathrm{g} \mathrm{L}^{-1}\right)$ & $4.3 \pm 0.1$ & $6.1 \pm 0.3$ & $9.9 \pm 0.5$ \\
Carbon recovery (\%) & $89.2 \pm 5.3$ & $72.3 \pm 3.9$ & $74.5 \pm 4.2$ \\
\hline
\end{tabular}

\section{Discussion}

In the literature, glycerol has been extensively employed as a carbon source in propionic acid fermentations by $P$. acidipropionici. Dishisha et al. (2013), employed glycerol and potato juice in a fermentative process using highcell-density sequential batches with cell recycle. In their study, final propionic acid concentrations of 43.8 and $50.8 \mathrm{~g} \mathrm{~L}^{-1}$ were reached using glycerol and potato juice, respectively. In the literature, another study (Liu et al. 2011) reports batch processes also using glycerol as a carbon source. In this study, the final concentrations of propionic, acetic, and succinic acid reached $18.1 \pm 0.6$, $0.54 \pm 0.09$, and $1.10 \pm 0.05 \mathrm{~g} \mathrm{~L}^{-1}$, respectively. In this same study, Liu et al. also report results using glucose as a carbon source; the final concentrations of propionic, acetic, and succinic acid reached $11.5 \pm 0.45,2.57 \pm 0.12$, and $0.55 \pm 0.03 \mathrm{~g} \mathrm{~L}^{-1}$, respectively. According to the results in the literature, the final concentration of propionic

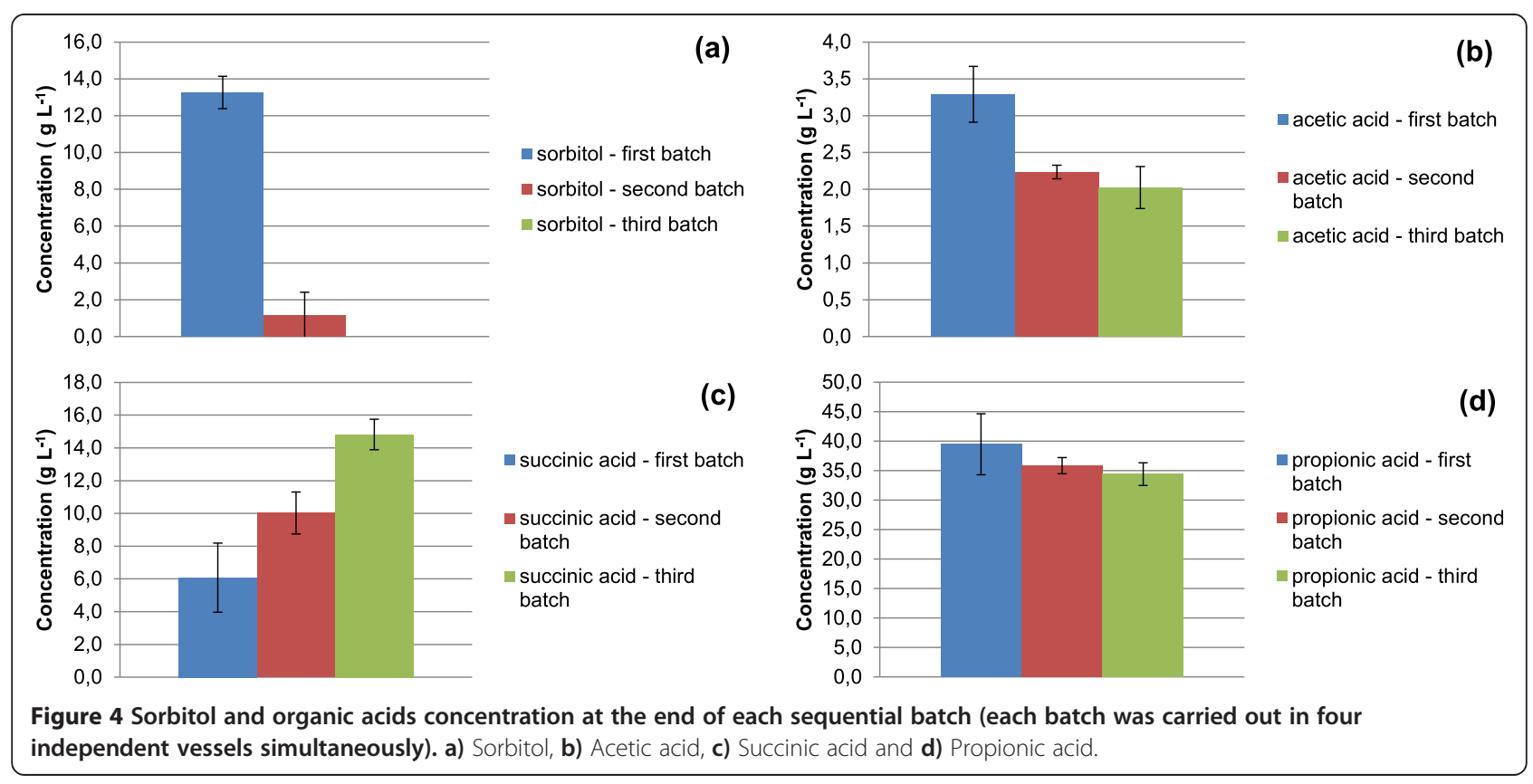


acid was higher when using glycerol and potato juice as a carbon sources in a high-cell-density process with sequential batches and cell recycle than that obtained in our studies using sorbitol. However, when using glycerol in batch processes, the final concentrations of propionic and succinic acid were lower than those obtained using sorbitol as a carbon source, as in the present work. In addition, fermentations employing sorbitol as a carbon source produced the most interesting results when compared to those obtained with glucose.

The percentages of recovered carbon were $89.2 \pm 5.3$, $72.3 \pm 3.9$, and $74.5 \pm 4.2 \%$ in the first, second, and third sequential batches, respectively. These results can be explained by the following hypothesis: the cells only used approximately $10 \%$ of the carbon source for maintenance, and the cell growth in the first batch and in the second and third sequential batches used approximately $30 \%$ due to the increase in cell concentration.

In sorbitol fermentations, a cellular maintenance coefficient of $0.039 \mathrm{~g} \mathrm{~g}^{-1} \mathrm{~h}^{-1}$ was obtained in the first batch, which increased from $0.044 \mathrm{~g} \mathrm{~g}^{-1} \mathrm{~h}^{-1}$ to $0.051 \mathrm{~g} \mathrm{~g}^{-1} \mathrm{~h}^{-1}$ in the second and third sequential batches. (Table 3 The meaning of abbreviations in Table 3 can be found in Table 1). These results are similar to those obtained by Goswami and Srivastava (2000) using lactose (initial concentration of $47.7 \mathrm{~g} \mathrm{~L}^{-1}$ ) as the carbon source in a fed-batch experiment, where the cellular maintenance coefficient was $0.038 \mathrm{~g} \mathrm{~g}^{-1} \mathrm{~h}^{-1}$. Table 3, shows acetic acid yields, $\mathrm{Y}_{\mathrm{AA} / \mathrm{S}}$, of $0.029 \mathrm{~g} \mathrm{~g}^{-1}$ for the second and third batches. These results are similar to those obtained by Zhang and Yang (2009), using an adapted culture of $P$. acidipropionici in FBB fermentation $\left(0.027 \pm 0.003 \mathrm{~g} \mathrm{~g}^{-1}\right)$. However, Blanc and Goma (1987), obtained a $0.140 \mathrm{~g} \mathrm{~g}^{-1}$ yield for acetic acid. Accordingly, when compared with household refuse enzymatic hydrolysate as a carbon source, sorbitol fermentation showed lower values of acetic acid yield. The most interesting result obtained for succinic acid yield, $\mathrm{Y}_{\mathrm{SA} / \mathrm{S}}$ in Table 3, is for the third batch $\left(0.212 \mathrm{~g} \mathrm{~g}^{-1}\right)$.

Table 3 Yield coefficients and cellular maintenance $(\mathrm{m})$ for the three sequential sorbitol fermentation batches using $P$. acidipropionici operating in four independent vessels

\begin{tabular}{lccc}
\hline & First batch & Second batch & Third batch \\
\hline$Y_{X / S}\left(\mathrm{~g} \mathrm{~g}^{-1}\right)$ & 0.366 & 0.326 & 0.279 \\
$Y_{\text {SA/S }}\left(\mathrm{g} \mathrm{g}^{-1}\right)$ & 0.097 & 0.132 & 0.212 \\
$Y_{\text {AA/S }}\left(\mathrm{g} \mathrm{g}^{-1}\right)$ & 0.052 & 0.029 & 0.029 \\
$Y_{\text {PA/S }}\left(\mathrm{g} \mathrm{g}^{-1}\right)$ & 0.613 & 0.419 & 0.438 \\
$Y_{\text {SA/X }}\left(\mathrm{g} \mathrm{g}^{-1}\right)$ & 0.264 & 0.404 & 0.760 \\
$Y_{\text {AA/X }}\left(\mathrm{g} \mathrm{g}^{-1}\right)$ & 0.143 & 0.090 & 0.102 \\
$Y_{\text {PA/X }}\left(\mathrm{g} \mathrm{g}^{-1}\right)$ & 1.673 & 1.288 & 1.570 \\
$\mathrm{~m}_{\left(\mathrm{g} \mathrm{g}^{-1} \mathrm{~h}^{-1}\right)}$ & 0.039 & 0.044 & 0.051 \\
\hline
\end{tabular}

Table 4 Organic acids and cell growth productivity for the three sequential sorbitol fermentation batches using $P$. acidipropionici operating in four independent vessels

\begin{tabular}{lccc}
\hline & First batch & Second batch & Third batch \\
\hline Succinic acid $\left(\mathrm{g} \mathrm{L}^{-1} \mathrm{~h}^{-1}\right)$ & 0.09 & 0.1 & 0.2 \\
Acetic acid $\left(\mathrm{g} \mathrm{L}^{-1} \mathrm{~h}^{-1}\right)$ & 0.05 & 0.03 & 0.03 \\
Propionic acid $\left(\mathrm{g} \mathrm{L}^{-1} \mathrm{~h}^{-1}\right)$ & 0.6 & 0.5 & 0.5 \\
Cell growth $\left(\mathrm{g} \mathrm{L}^{-1} \mathrm{~h}^{-1}\right)$ & 0.06 & 0.09 & 0.14 \\
\hline
\end{tabular}

Zhang and Yang (2009) obtained lower results for $\mathrm{Y}_{\mathrm{SA} / \mathrm{S}}$ $\left(0.073 \pm 0.002 \mathrm{~g} \mathrm{~g}^{-1}\right)$. In the present study, $\mathrm{Y}_{\mathrm{X} / \mathrm{S}}$ was $0.366 \mathrm{~g} \mathrm{~g}^{-1}$ in the first batch, similar to the $0.362 \mathrm{~g} \mathrm{~g}^{-1}$ value obtained by Goswami and Srivastava (2000) in their study with lactose as a carbon source. The definitions of the abbreviations used in Table 3 can be found in Table 1.

In our study, the productivity of propionic acid was approximately $0.5 \mathrm{~g} \mathrm{~L}^{-1} \mathrm{~h}^{-1}$ (Table 4). (Blanc and Goma 1987) obtained similar propionic acid productivity $\left(0.4 \mathrm{~g} \mathrm{~L}^{-1} \mathrm{~h}^{-1}\right)$ with sugar mixtures from hydrolysis of household refuse in batch experiments. Another work (Liu et al., 2012) reports lower propionic acid productivities using xylose $\left(0.23 \mathrm{~g} \mathrm{~L}^{-1} \mathrm{~h}^{-1}\right)$ and corncob molasses $\left(0.28 \mathrm{~g} \mathrm{~L}^{-1} \mathrm{~h}^{-1}\right)$ in fed-batch experiments. Dishisha et al. (2012) studied propionic acid production from glycerol using immobilized cells on polyethylenimine-treated Poraver (PEI-Poraver) and Luffa (PEI-Luffa). In their study, productivities of propionic acid were 0.86 and $0.29 \mathrm{~g} \mathrm{~L}^{-1} \mathrm{~h}^{-1}$ using PEI-Poraver and PEI-Luffa, respectively. Blanc and Goma (1987) obtained a productivity of $0.10 \mathrm{~g} \mathrm{~L}^{-1} \mathrm{~h}^{-1}$ for acetic acid while in the present work, the productivity of acetic acid decreased from $0.05 \mathrm{~g} \mathrm{~L}^{-1} \mathrm{~h}^{-1}$ in the first batch to $0.03 \mathrm{~g} \mathrm{~L}^{-1} \mathrm{~h}^{-1}$ in the third sequential batch (Table 4). Other results are compared in Table 5. The definitions of the abbreviations used in Table 5 can be found in Table 1.

In the present study, the average propionic acid/acetic acid (P/A) molar ratio was increased from 9.7 in the first batch to 13.8 in the third sequential batch when using sorbitol as a carbon source. Liu et al. (2011) obtained a higher P/A molar ratio of 27.1 using glycerol and a lower P/A molar ratio of 3.63 using glucose as a carbon source. Another study (Zhu et al. 2010) using glycerol as a carbon source reached a P/A mass ratio of 13.10 (P/A molar ratio of 10.6) which is similar to the P/A molar ratio of the first batch (9.7) using sorbitol as a carbon source. As expected, the propionic acid/succinic acid (P/S) molar ratio decreased from 10.3 in the first batch to 3.7 in the third sequential batch, once the concentration of succinic acid increased from $6.1 \pm 2.1$ to $14.8 \pm 0.9 \mathrm{~g} \mathrm{~L}^{-1}$ and that of propionic acid decreased from $39.5 \pm 5.2$ to $34.4 \pm 1.9 \mathrm{~g} \mathrm{~L}^{-1}$ (Table 6). 


\begin{tabular}{|c|c|c|c|c|c|c|c|c|}
\hline Strain & Carbon source & $\begin{array}{l}\text { Immobilization } \\
\text { matrix }\end{array}$ & Mode of operation & $\begin{array}{c}\text { Propionic } \\
\text { acid }\left(\mathrm{g} \mathrm{L}^{-1}\right)\end{array}$ & $\begin{array}{l}\text { Productivity } \\
\left(\mathrm{g} \mathrm{L}^{-1} \mathrm{~h}^{-1}\right)\end{array}$ & $Y_{P A / S}\left(g^{-1}\right)$ & P/A ratio $\left(\mathrm{g} \mathrm{g}^{-1}\right)$ & Reference \\
\hline ATCC 25562 & Glycerol $30\left(\mathrm{~g} \mathrm{~L}^{-1}\right)$ & - & Batch & 20 & 0.24 & 0.68 & 45.6 & Barbirato et al. (1997) \\
\hline ATCC 25562 & Glycerol $30\left(\mathrm{~g} \mathrm{~L}^{-1}\right)$ & Ca alginate beads & Recycle batch & 19.3 & 3.0 & 0.63 & 113.5 & Bories et al. (2004) \\
\hline ATCC 25562 & Glycerol $20\left(\mathrm{~g} \mathrm{~L}^{-1}\right)$ & - & Batch & 12 & 0.42 & 0.64 & 6 & Himmi et al. (2000) \\
\hline ATCC 4965 & Glycerol $20\left(\mathrm{~g} \mathrm{~L}^{-1}\right)$ & - & Uncontrolled-pH Batch & 6.77 & 0.05 & 0.72 & $\begin{array}{l}\text { Without acetic } \\
\text { acid production }\end{array}$ & Coral et al. (2008) \\
\hline \multirow[t]{2}{*}{ CGMCC 1.2230} & Glycerol $50\left(\mathrm{~g} \mathrm{~L}^{-1}\right)$ & - & Batch & $28.53 \pm 0.82$ & 0.19 & 0.57 & $11.14 \pm 0.62$ & Zhu et al. (2010) \\
\hline & Glycerol $80\left(\mathrm{~g} \mathrm{~L}^{-1}\right)$ & & & $32.00 \pm 0.91$ & 0.09 & 0.40 & $6.15 \pm 0.31$ & \\
\hline \multirow[t]{7}{*}{ DSM 4900} & Glycerol $42 \pm 0.50\left(\mathrm{~g} \mathrm{~L}^{-1}\right)$ & - & Batch & $19.46 \pm 0.63$ & 0.34 & 0.51 & 17.9 & Dishisha et al. (2012) \\
\hline & Glycerol $63.6 \pm 0.90\left(\mathrm{~g} \mathrm{~L}^{-1}\right)$ & - & & $26.31 \pm 0.78$ & 0.26 & 0.51 & 47.8 & \\
\hline & Glycerol $43.3 \pm 0.01\left(\mathrm{~g} \mathrm{~L}^{-1}\right)$ & PEI-Luffa & & $21.70 \pm 0.02$ & 0.30 & 0.58 & 27.8 & \\
\hline & Glycerol $63.2 \pm 0.03\left(\mathrm{~g} \mathrm{~L}^{-1}\right)$ & PEl-Luffa & & $26.00 \pm 0.02$ & 0.16 & 0.57 & 38.2 & \\
\hline & Glycerol $42 \pm 0.01\left(\mathrm{~g} \mathrm{~L}^{-1}\right)$ & PEl-Poraver & & $20.09 \pm 0.01$ & 0.86 & 0.51 & 28.7 & \\
\hline & Glycerol $66.6 \pm 0.05\left(\mathrm{~g} \mathrm{~L}^{-1}\right)$ & PEl-Poraver & & $28.39 \pm 0.02$ & 0.43 & 0.51 & 55.7 & \\
\hline & Glycerol $84.6 \pm 0.00\left(\mathrm{~g} \mathrm{~L}^{-1}\right)$ & PEI-Poraver & & $35.23 \pm 0.01$ & 0.35 & 0.47 & 15.3 & \\
\hline \multirow[t]{2}{*}{ ATCC 4875} & Xylose & - & Fed-batch & 53.2 & 0.23 & a & 5.2 & Liu et al. (2012) \\
\hline & Corncob molasses & & & 71.8 & 0.28 & a & $\sim 4.8$ & \\
\hline NRRLB-3569 & Household refuse - & - & Batch & 27.6 & 0.40 & 0.552 & 3.33 & Blanc and Goma (1987) \\
\hline \multirow[t]{2}{*}{ ATCC 4875} & Glycerol $\left(40 \mathrm{~g} \mathrm{~L}^{-1}\right)$ & - & Batch & $19.3 \pm 0.06$ & $0.026 \pm 0.002$ & $0.55 \pm 0.01$ & $>100$ & Zhang and Yang (2009) \\
\hline & & $\begin{array}{l}\text { Fibrous-bed } \\
\text { bioreactor (FBB) }\end{array}$ & Fed-batch & $19.7 \pm 1.0$ & $0.17 \pm 0.04$ & $0.52 \pm 0.01$ & $26 \pm 4$ & \\
\hline \multirow{2}{*}{$\begin{array}{l}\text { ATCC } 4875 \\
\text { ACK-Tet }\end{array}$} & & - & Batch & $26.0 \pm 0.6$ & $0.10 \pm 0.03$ & $0.54 \pm 0.02$ & $29 \pm 3$ & \\
\hline & & $\begin{array}{l}\text { Fibrous-bed } \\
\text { bioreactor (FBB) }\end{array}$ & Recycle-batch & $23.0 \pm 1.3$ & $0.25 \pm 0.03$ & $0.59 \pm 0.02$ & $22 \pm 2$ & \\
\hline \multirow{2}{*}{$\begin{array}{l}\text { CGMCC } 1.2225 \\
\text { (ATCC4965) }\end{array}$} & Glycerol $\left(40 \mathrm{~g} \mathrm{~L}^{-1}\right)$ & - & Batch & $18.1 \pm 0.65$ & 0.108 & $0.475 \pm 0.017$ & 33.5 & Liu et al. (2011) \\
\hline & Glucose $\left(40 \mathrm{~g} \mathrm{~L}^{-1}\right)$ & & & $11.5 \pm 0.45$ & 0.068 & $0.303 \pm 0.012$ & 4.5 & \\
\hline \multirow[t]{3}{*}{ ATCC 4875} & Sorbitol $\left(80 \mathrm{~g} \mathrm{~L}^{-1}\right)$ & - & Sequential batch -first batch & $39.5 \pm 5.2$ & 0.6 & 0.613 & 12.0 & This work \\
\hline & & & Sequential batch -second batch & $35.8 \pm 1.4$ & 0.5 & 0.419 & 16.0 & \\
\hline & & & Sequential batch - third batch & $34.4 \pm 1.9$ & 0.5 & 0.438 & 17.0 & \\
\hline
\end{tabular}

${ }^{a}$ Data not calculated. 
Table 6 Propionic acid/acetic acid (P/A) and propionic acid/succinic acid $(P / S)$ productivity ratios of three sequential sorbitol fermentation batches using $P$. acidipropionici operating in four independent vessels

\begin{tabular}{lcc}
\hline & P/A ratio $\left(\mathbf{m o l ~} \mathbf{~ m o l}^{\mathbf{- 1}}\right)$ & P/S ratio $\left(\mathbf{m o l ~}_{\mathbf{~ m o l}}^{\mathbf{- 1}}\right)$ \\
\hline First batch & 9.7 & 10.3 \\
Second batch & 13.0 & 5.7 \\
Third batch & 13.8 & 3.7 \\
\hline
\end{tabular}

The best propionic acid yield obtained, $\mathrm{Y}_{\mathrm{PA} / \mathrm{S}}$, was $0.613 \mathrm{~g} \mathrm{~g}^{-1}$ for the first batch. This result was higher than the values found in the literature; for example, Blanc and Goma (1987), reached a lower propionic acid yield of $0.552 \mathrm{~g} \mathrm{~g}^{-1}$ using products of hydrolysis of household refuse; Zhang and Yang (2009), using an adapted culture of $P$. acidipropionici in FBB fermentation, obtained a $\mathrm{Y}_{\mathrm{PA} / \mathrm{S}}$ value of $0.59 \pm 0.02$; and Liu et al. (2011), obtained a $\mathrm{Y}_{\mathrm{PA} / \mathrm{S}}$ of $0.475 \pm 0.017$ and $0.303 \pm 0.012$ from glycerol and glucose, respectively. Dishisha et al. (2012), obtained the best result for propionic acid yield $\left(0.74 \mathrm{~mol} \mathrm{~mol}^{-1}\right.$ or $0.595 \mathrm{~g} \mathrm{~g}^{-1}$ ) from glycerol. When using sorbitol, as we reported herein, it is possible to obtain a superior yield of $1.51 \mathrm{~mol} \mathrm{~mol}^{-1}\left(0.613 \mathrm{~g} \mathrm{~g}^{-1}\right)$ (see Table 5).

Substrate consumption rates and biomass rates were similar in each batch. The succinic acid production rate increased from $0.022 \mathrm{~g} \mathrm{~h}^{-1}$ to $0.053 \mathrm{~g} \mathrm{~h}^{-1}$ while that of acetic acid (from $0.012 \mathrm{~g} \mathrm{~h}^{-1}$ to $0.007 \mathrm{~g} \mathrm{~h}^{-1}$ ) and propionic acid (from $0.137 \mathrm{~g} \mathrm{~h}^{-1}$ to $0.109 \mathrm{~g} \mathrm{~h}^{-1}$ ) decreased over the batches. The specific cell growth rate remained at a constant value of $0.014 \mathrm{~h}^{-1}$ over the batches (Table 7; the definitions of the abbreviations used in Table 7 can be found in Table 1). Zhang and Yang (2009) obtained a specific cell growth rate of $0.050 \pm 0.002 \mathrm{~h}^{-1}$ when working with the original culture and $0.16 \pm 0.02 \mathrm{~h}^{-1}$ with the adapted culture in free-cell fermentation.

Table 7 Instantaneous and specific rates of the three sequential sorbitol fermentation batches using $P$. acidipropionici operating in four independent vessels

\begin{tabular}{lccc}
\hline & First batch & Second batch & Third batch \\
\hline$r_{S}=-d S / d t\left(\mathrm{~g} \mathrm{~h}^{-1}\right)$ & -0.224 & -0.272 & -0.250 \\
$r_{\mathrm{SA}}=\mathrm{dP} / \mathrm{dt}\left(\mathrm{g} \mathrm{h}^{-1}\right)$ & 0.022 & 0.036 & 0.053 \\
$r_{\mathrm{AA}}=\mathrm{dP} / \mathrm{dt}\left(\mathrm{g} \mathrm{h}^{-1}\right)$ & 0.012 & 0.008 & 0.007 \\
$r_{\mathrm{PA}}=\mathrm{dP} / \mathrm{dt}\left(\mathrm{g} \mathrm{h}^{-1}\right)$ & 0.137 & 0.114 & 0.109 \\
$r_{\mathrm{x}}=\mathrm{dX} / \mathrm{dt}\left(\mathrm{g} \mathrm{h}^{-1}\right)$ & 0.082 & 0.089 & 0.070 \\
$\mu_{\mathrm{S}}=1 / \mathrm{X}(-\mathrm{dS} / \mathrm{dt})\left(\mathrm{h}^{-1}\right)$ & -0.039 & -0.044 & -0.051 \\
$\mu_{\mathrm{SA}}=1 / \mathrm{X}(\mathrm{dP} / \mathrm{dt})\left(\mathrm{h}^{-1}\right)$ & 0.004 & 0.006 & 0.011 \\
$\mu_{\mathrm{AA}}=1 / \mathrm{X}(\mathrm{dP} / \mathrm{dt})\left(\mathrm{h}^{-1}\right)$ & 0.002 & 0.001 & 0.001 \\
$\mu_{\mathrm{PA}}=1 / \mathrm{X}(\mathrm{dP} / \mathrm{dt})\left(\mathrm{h}^{-1}\right)$ & 0.024 & 0.018 & 0.022 \\
$\mu_{\mathrm{x}}=1 / \mathrm{X}(\mathrm{dX} / \mathrm{dt})\left(\mathrm{h}^{-1}\right)$ & 0.014 & 0.014 & 0.014 \\
\hline
\end{tabular}

S: substrate (sorbitol); SA: succinic acid; AA: acetic acid; PA: propionic acid; $\mathrm{X}$ : cells.
In conclusion, the final concentration of propionic acid obtained in this study using sorbitol as a carbon source was higher than that obtained in other studies using glucose, household refuse, and glycerol (in some specific operation modes) presented in the literature. Employing sorbitol, an unexplored carbon source, in fermentation reactions, allowed reducing the acetic acid yield when compared to glucose and household refuse enzymatic hydrolysate as carbon sources. Furthermore, these results, all obtained in quadruplicate, are important for the development of a continuous fermentation process in the future.

\section{Competing interests}

The authors declare that they have no competing interests.

\section{Authors' contributions}

JCD carried out the fermentation studies including planning, data acquisition and analysis. JCD has also performed the statistical analysis and has been drafting this manuscript. GPV, PJSM and JARR were involved in the global project and they have made substantial contributions to conception and design. They were involved in planning experiments, data interpretation and analysis, besides contributed in drafting this manuscript. All authors read and approved the final manuscript.

\section{Acknowledgements}

The authors thank the São Paulo Research Foundation (grant 2011/51861-9), Coordination for the Improvement of Higher Education Personnel - CAPES, and National Council for Scientific and Technological Development - CNPq for their financial support, and BRASKEM S/A for a scholarship.

\section{Author details}

${ }^{1}$ Institute of Chemistry, University of Campinas, Campinas, SP 13083-970, Brazil. ${ }^{2}$ School of Chemical Engineering, University of Campinas, Campinas, SP 13083-852, Brazil.

Received: 11 August 2014 Accepted: 6 January 2015

Published online: 20 February 2015

\section{References}

Adsul MG, Singhvi MS, Gaikaiwari SA, Gokhale DV (2011) Development of biocatalyst for production of commodity chemicals from lignocellulosic biomass. Bioresour Technol 102:4304-4312

Barbirato F, Chedaille D, Bories A (1997) Propionic acid fermentation from glycerol: comparison with conventional substrates. Appl Microbiol Biotechnol 47:441-446

Bizzari SN, Gubler R (2004) Chemical Economics handbook. IHS Chemical, Englewood, pp 1-29

Blanc P, Goma G (1987) Production of acetic and propionic acids from household refuse enzymatic hydrolysate by Propionibacterium acidipropionici. Bioprocess Eng 2:175-179

Bories A, El Himmi H, Jauregui JJA, Pelayo-Ortiz C, Gonzales VA (2004) Fermentation du glycérol chez des Propionibactéries et optimisation de la production d'acide propionique. Sci Aliment 24:121-136

Boyaval P, Corre C (1995) Production of propionic acid. Lait 75:453-461

Cheng K-K, Zhao X-B, Zeng J, Zhang J-A (2012) Biotechnological production of succinic acid: current state and perspectives. Biofuels. Bioprod Bioref 6:302-318

Coral J, Karp SG, Vandenberghe LPS, Parada JL, Pandey A, Soccol CR (2008) Batch fermentation model of propionic acid production by Propionibacterium acidipropionici in different carbon sources. Appl Biochem Biotechnol 151:333-341

Dishisha T, Alvarez MT, Hatti-Kaul R (2012) Batch- and continuous propionic acid production from glycerol using free and immobilized cells of Propionibacterium acidipropionici. Biores Technol 118:553-562 
Dishisha T, Stahl A, Lundmark S, Hatti-Kaul R (2013) An economical biorefinery process for propionic acid production from glycerol and potato juice using high cell density fermentation. Biores, Technol 135:504-512

Feng X, Chen F, Xu H, Wu B, Li H, Li S, Ouyang P (2011) Green and economical production of propionic acid by Propionibacterium freudenreichii CCTCC M207015 in plant fibrous-bed bioreactor. Bioresour Technol 102:6141-6146

Goswami V, Srivastava AK (2000) Fed-batch propionic acid production by Propionibacterium acidipropionici. Biochem Eng J 4:121-128

Goswami V, Srivastava AK (2001) Propionic acid production in an in-situ cell retention bioreactor. Appl Microbiol Biotechnol 56:676-680

Hatti-Kaul R, Tornvall U, Gustafsson L, Borjesson P (2007) Industrial biotechnology for the production of bio-based chemicals: a cradle-to-grave perspective. Trends Biotechnol 25:119-124

Himmi EH, Bories A, Boussaid A, Hassani L (2000) Propionic acid fermentation of glycerol and glucose by Propionibacterium acidipropionici and Propionibacterium freudenreichii ssp. shermanii. Appl Microbiol Biotechnol 53:435-440

Huang YL, Wu ZT, Zhang LK, Cheung CM, Yang ST (2002) Production of carboxylic acids from hydrolyzed corn meal by immobilized cell fermentation in a fibrous-bed bioreactor. Bioresour Technol 82:51-59

Kagliwal LD, Survase SA, Singhal RS, Granström T (2013) Wheat flour based propionic acid fermentation: An economic approach. Bioresour Technol 129:694-699

Koussémon M, Combet-Blanc Y, Ollivier B (2003) Glucose fermentation by Propionibacterium microaerophilum: effect of $\mathrm{pH}$ on metabolism and bioenergetics. Curr Microbiol 46:141-145

Liu Y, Zhang YG, Zhang RB, Zhang F, Zhu J (2011) Glycerol/Glucose cofermentation: one more proficient process to produce propionic acid by Propionibacterium acidipropionici. Curr Microbiol 62:152-158

Liu Z, Ma C, Gao C, Xu P (2012) Efficient utilization of hemicellulose hydrolysate for propionic acid production using Propionibacterium acidipropionici. Biores Technol 114:711-714

Mahmoud M, Levin RE (1993) Fermentative production of propionic acid in hydrolyzed cod (Gadus morhus). J Food Biochem 17:201-214

Minh DP, Besson M, Pinel C, Fuertes P, Petitjean C (2010) Aqueous-phase hydrogenation of biomass-based succinic acid to 1,4-butanediol over supported bimetallic catalysts. Top Catal 53:1270-1273

Muzumdar AV, Sawant SB, Pangarkar VGL (2004) Reduction of maleic acid to succinic acid on titanium cathode. Org Process Res Dev 8:685-688

Ranucci E, Liu Y, Lindblad MS, Albertsson A-C (2000) New biodegradable polymers from renewable sources. High molecular weight poly(ester carbonate)s from succinic acid and 1,3-propanediol. Macromol. Rapid Commun 21:680-684

Ruhal R, Aggarwal S, Choudhury B (2011) Suitability of crude glycerol obtained from biodiesel waste for the production of trehalose and propionic acid. Green Chem 13:3492-3498

Sabra W, Dietz D, Zeng AP (2013) Substrate-limited co-culture for efficient production of propionic acid from flour hydrolysate. Appl Microbiol Biotechnol 97:5771-5777

Suwannakham S (2005) Metabolic engineering for enhanced propionic acid fermentation by Propionibacterium acidipropionici. Dissertation, The Ohio State University, Ph. D

Tsoskounogiou M, Ayerides G, Tritopoulou E (2008) The end of cheap oil: current status and prospects. Energy Policy 36:3797-3806

VanBriesen JM (2002) Evaluation of methods to predict bacterial yield using thermodynamics. Biodegradation 13:171-190

Wang Z, Yang S-T (2013) Propionic acid production in glycerol/glucose co-fermentation by Propionibacterium freudenreichii subsp. shermanii. Bioresour Technol 137:116-123

Yang ST, Huang Y, Hong C (1995) A novel recycle batch immobilized cell Bioreactor for propionate production from whey lactose. Biotechnol Bioeng 45:379-386
Zhang A, Yang ST (2009) Propionic acid production from glycerol by metabolically engineered Propionibacterium acidipropionici. Process Biochem 44:1346-1351

Zhu Y, Li J, Tan M, Liu L, Jiang L, Sun J, Lee P, Du G, Chen J (2010) Optimization and scale-up of propionic acid production by propionic acid-tolerant Propionibacterium acidipropionici with glycerol as the carbon source. Bioresour Technol 101:8902-8906

\section{Submit your manuscript to a SpringerOpen ${ }^{\odot}$ journal and benefit from:}

- Convenient online submission

- Rigorous peer review

- Immediate publication on acceptance

- Open access: articles freely available online

- High visibility within the field

- Retaining the copyright to your article

Submit your next manuscript at $>$ springeropen.com 